\title{
Legal Protection for Justice Seeker Through State Administrative Court
}

\author{
Enny Agustina \\ \{ennyagustinadua@yahoo.com\} \\ Faculty of Law, Universitas Kader Bangsa, Palembang, Indonesia
}

\begin{abstract}
This research is aimed to analyze how the implementation of legal protection for justice seekers through state administrative courts and what steps can be taken so that legal protection for justice seekers can be binding. The approach was used a statute approach and concept approach. The result of the research show that legal protection for justice seekers can be realized in case there was a good faith from the state administrative agency or officials who were subject to the decision to implement the judicial decision of the state administration and the supervision and activeness of the community in guarding the implementation of the decision. Base on the correct evidence of the parties to the dispute, the verdict said to provide legal protection. It was produced from fair trial process and a fair, and also decision may be exercised
\end{abstract}

Keywords: Legal Protection, Justice Seeker, State Administrative Court.

\section{INTRODUCTION}

Legal protection is needed by the citizenry, especially in welfare state type. As is known, in the welfare state had vulnerable arise friction of interest between the community and the government when the government had a very big role, even entered on the aspects of private life of its citizenry. Therefore, the community needed a clear legal protection if the people perceive their interests were disturbed by a legal action of the government, so in this case the government also had control over the authority possessed.

Legal protection (rechtsbescherming) related to law enforcement can be interpreted as provide the access to justice for justice seekers. Access to justice in this case was defined as given fair and impartial treatment and also was given everything accord to its rights and portions. Legal protection for community disputes with the government was also a form of respect for human rights that was basically based on the needed for a clean and

Responsible governance condition. On the other hand, on the legal state framework, a clean and responsible government was part of the requirements of a country to be called a legal state [1]. Governance is a central point that can perform various actions related to its position. Therefore, a real form of legal protection was needed for the citizenry as justice seekers so that the citizenry can be protected from abuse and abuse of authority by the government. Based on that can be distinguished two kinds of legal protection for the citizenry. It was protection of preventive law and repressive law protection. In preventive legal protection, the citizenry were given the opportunity to file an objection (inspraak) or opinion 
before a government decision got a definitive form of determination. Thus, preventive legal protection aimed to prevent the occurrence of disputes, while repressive legal protection aimed to resolve disputes.

The State Administrative Tribunal was divided into three types: the function of advisory, referral and judiciary of the three functions can see that there were two functions that precede the function of the judiciary. First, the function of the advisory in the State Administrative Court was strived that the

dispute between the people and the government can minimize, while the referral function for the achievement of peaceful efforts to resolve the dispute between the government and the people. Thus, the principle of harmony between public relations and government can carry out ideally. However, the settlement of disputes in a peaceful manner did not mean abandoned the principles and rules of law that applied but rather to the discovery of awareness of the principle and the rule of law was not intended for the determination of the winner or the losers, but rather the state of mutual understanding and recognizing the nature of the existence of existing laws and regulations

In general there are three kinds of government actions (bestuurhandeling). First of all, the actions of the government in terms of made laws and regulations (regeling). Second, the actions of the government in the issuance of decisions (beschikking). Third, the actions of government in the field of civil law (materialele daad). Government actions in regeling and beschikking occur in the fielded of public law, so it must be subject to public law, while the actions of the government in terms of civil, then subject to the provisions of civil law. The Government may be deemed to be unlawful in violation of the subjective rights of others if the government commits an act sourced in a civil law relationship and violates the provisions of that law and commits an act which originated in public law and violated the provisions of the law. The consequences of such government interference were the emergence of a number of irregularities such as abuse of authority (detournement de pouvoir), exceeding power limits (exces de pouvoir), arbitrary (willekeur) and so on [1].

In order to provide legal protection for justice seekers, Law Number. 5/1986 on Law Number. 9/2004 in conjunction with Law Number. 51 Year 2009 on the State Administrative Court, pursuant to Article 144 called the State Administration Judicature Act. The position of the State Administrative Court which is expressly regulated in the constitution as a reflection of the provision of legal protection for the people due to the attitude of acts or acts of government was placed at a high position in the life of the nation and state in Indonesia. This is considering that Indonesia adheres to the type of modern legal state (moderne rechtstaat) better known as the type of welfare state (welfare state type) which resulted in extensive government intervention in aspects of people's lives.

Handling of legal protection for the people by the judiciary including by the State Administrative Court in this case was a repressive legal protection. Legal protection facilities for repressive people in Indonesia were known to be a few bodies and were grouped into the following groups (Sri Pudyatmoko dan Ridwan tjandra, 1996):

1. Courts within the State Administrative Courts;

2. Courts within the General Courts;

3. Government agencies which were administrative apparatuses;

4. Special agencies.

One form of legal protection for the people carried out through the State Administrative Court was a form of legal protection for the people in dispute with the Board or the State Administration Officer. The principle of legal protection for the people who in practice put forward the principle of equality before the law, in this case the principle of justice taken 
precedence before the application of legal norms in order to achieve harmony of relations between the government and the people based on the principle of harmony.

State Administrative Court was a court that can resolve the dispute because the community was not satisfied or harmed by the actions of the government; at least the act is not fun. The incidence of such loss or discomfort was caused by the following matters [2]:

1. The decision of the organ of state or government administration were deemed inaccurate (onjuist).

2. Decisions of organs of state or government administration were considered in violation of the law (onwetmatig).

3. The decision of the organ of state or government administration were considered unwise (ondoelmatig).

4. The decision of the organ of state or government administration were considered unlawful (onrechtmatig).

The function of State Administrative Court which should be able to provide legal protection to the community, has not yet been fully realized. Legal efforts by justice seekers often get unsatisfactory results, or even if they arrive at the hearing and the ultimate verdict is the justice seeker who were won, sometimes the government or the ruler does not run the content of the decision that already has such permanent legal force. Based on the background that has been described above, there are two problem formulation that can be arranged in this research, that is:

1. How is the Implementation of Legal Protection of Seekers of Justice through State Administrative Court?

2. What steps can be taken to ensure that legal protection for justice seekers through the State Administrative Court can be binding?

In accordance with the issues that were the focus of this research, the purpose of this study were to describe the legal protection for the justice seekers through the State Administrative Court and find the steps that can be done so that legal protection for the justice seekers can be binding, while the benefit of this research was for legal protection for justice seekers through the State Administrative Court can be realized as well as the State Administration Officers or Officers more cautious in issuing a Decision of State Administration so as not to harm the community.

\section{METHOD}

Research method was used in this research was normative law research method. Normative law research method or literature law research method was a method or method was used in legal research conducted by examining existing library materials include written legal norms. In relation to this type of research which is a normative legal research, the correlation between das sein and das sollen was analyzed by normative juridical with qualitative approach. In the Qualitative approach, the analysis was done to answer the questions in the research problem matters and was carried out through the process of developing a logical series of evidence. The process of establishing the road of proof was done slowly so that an initial understanding of the main factors can be used to develop a logical relationship and can be explained in an analysis [3].

The first stages of normative legal research is research that aims to get the law that was objective, namely by conducting research on legal issues. The second stage of normative legal 
research is research aimed at obtaining a subjective law. In normative legal research, the research conducted was descriptive that describes the symptoms in the community environment to a problem under study, the approach was qualitative approach.

In the normative legal research method, there are three types of library materials was used :

1. The primary legal material, which were the binding legal material or which requires the person to comply with it, such as the laws and regulations of the judge. The primary legal material was used in this study was Law No. 5 of 1986 Jo Law No. 9 of 2004 Jo Law 51

Year 2009 on the State Administrative Court.

2. Secondary legal materials

Secondary law was a non-binding legal material but explains the primary legal material derived from the opinions of experts or doctrines. The meaning of secondary materials in this study was the doctrine contained in books and legal journals.

3. Tertiary legal materials

Tertiary legal material was a legal material that supports primary legal materials and secondary legal materials by providing insight into other legal materials.

In legal research there are several approaches, with the approach the researchers got information from various aspects of the issues to be discussed. The approach was used in legal research was [4]:

1.Statute approach;

2.Case approach;

3.Historical Approach ;

4. Comparative approach (comparative approach)

5. Conceptual approach (conceptual approach).

The approach was used in this research was the approach of law (statute approach) and conceptual approach (conceptual approach).

\section{DISCUSSION}

\subsection{Implementation of Legal Protection for Justice Seekers through State Administrative Court.}

Legal protection for the people as seekers of justice against an adverse State Administration Decree basically stems from the concept of recognition and protection of human rights. State Administration Body or officer was a party having power to take action to achieve prosperity for all people. The Government was a party to the disputing power with the people as the governed party in an unequal position. Therefore, the State Administrative Court is aimed at providing legal protection for the people in conflict with the government so as to obtain justice in an equal position.

The State Administrative Court was one manifestation of the fulfillment of the rights of the people in dispute with the government, included as a form of guarantee to obtain justice when filing a lawsuit related to the state administrative decree issued by the state administrative officer [1]. State Administration intended in this case was a state administration that performs functions to administer a government or executive ruled, whether at the central or regional level, to implement it in accordance with applicable laws and regulations. The said party has the authority to make decisions which contain state administrative law actions based on concrete, individual, and final legislative regulations and cause consequences for a person 
or a civil legal entity. The effect was sometimes contrary to the interests of the community so that then disputed.

The State Administrative Judiciary was an institution born at the time of development of the modern legal system has been developed based on the needs of modern legal system consisting of formal processes, in which formal processes together with the informal process form the fabric of procedures which were the heart of the law [5]. In the modern legal system, recognition of the protection of human rights has a sizeable portion and one of them is realized through the provision of legal protection for the people. Formal processes include bureaucracy, administration, transformation, and sub-systems that synergistically form a braid of the State Administrative Court system [6]. The main principle of the judiciary should be based on the principle of law that serves human beings so that the law is for human beings and not the other way around, therefore the justice seekers should not adapt to the judicial machinery even if the justice seeker must submit and follow the judicial system [7].

The justice seeker side, the State Administrative Court was a media that was expected to solve the problems [8]. From a procedural point of view, justice seekers want the State Administrative Court to be able to solve the problem quickly and through a less complicated process. Whereas from the substantial point of the justice seekers, the State [8] Administrative Court can create decision products that actually solve the problems and be able to provide a sense of justice for the public who lit with the state administrative officials. Justice in this case becomes very important because the people in the judiciary.

Legal protection for justice seekers conducted by the State Administrative Court cannot be separated from the principles of the State Administrative Court. The principles of the State Administrative Judicature are as follows [9]:

1. Principle of Presumption Rechtmatig, which implies that any act of the authorities shall always be deemed true until there was a denunciation, so that a State Administration Decision being sued shall not be the basis for delaying the implementation of the said defendant's decision;

2. The Free Proof Principle, meaning that the judge has the freedom to determine the things that must be proven, and the burden of proof and the evidentiary judgment; the principle was saw in article 107 of the State Administration Judicature law

3. Principle of Activity of Judge (dominus litis), the activeness of judges in this case was intended to offset the position of unlawful litigants, because the defendant was the Board or the State Administration Officer who controls the legislation relating to the authority or basis of the decision were sued, while the plaintiff does not necessarily possess the rules underlying the issuance of the decision;

4. The Principle of Judgment of Courts having Strength of Binding (erga omnes), this principle relates to a State Administration dispute which is a dispute in the realm of public law so that the legal consequences arising from the judges' judgment shall have legal force not only to the parties to the dispute ;

The four principles of the State Administrative Court are intended for legal protection of justice seekers. A justice seeker who filed a lawsuit over a State Administrative Decision in this case is entitled to legal protection and is treated equally in the eyes of the law even though the party sued was the State Administration Officer.

In this case, the public who filed the lawsuit should pay attention to some of the characteristics of government legal action in the field of public law as follows [10]:

1. The nature or characteristics of a State Administrative Decree (beschikking) shall always be deemed valid as long as it has not been proven otherwise, so in principle the State Administration Decree shall be immediately enforceable. In which case, the state 
administration decision made must not be considered wrong before it was declared wrong, so it cannot postpone implementation declared wrong.

2. The principle of protection of public or public interest that stands out apart from the protection of the individual. This principle is intended to protect the interests of the common people broadly above individual interests;

3. The principle of self respect or self-obedience of the government apparatus against administrative judicial decisions. This principle relates to the implementation of the Decision of the State Administration in a voluntary and conscientious manner by the parties to the decision. This is related to the absence of coercive efforts in the State Administrative Court directly through a bailiff as well as civil law.

The lawsuit for the settlement of a State Administration dispute is a lawsuit concerning the validity or impropriety of a State Administrative Decision which causes a State Administrative dispute. In view of the lawsuit for the completion of the Decision of State Administration concerning the validity or impropriety of the State Administrative Decree, in fact for the settlement of the State Administration dispute does not recognize the existence of peace. Therefore, the possibility of peace among the parties litigating in the State Administration dispute can only be done outside the court. The facts then underlie the State Administrative Court will offer a dispute resolution by deliberation. The State Administrative Judiciary in this case shall seek a mediation step first and be offered to the parties in the State Administration dispute case so that the trial proceedings shall be the last attempt made if no agreement is reached through mediation between the litigants.

The authority possessed by the State Administrative Court was mentioned clearly in the provisions of the State Administration Judicature law. Article 47 of the law mentions that the State Administrative Court was responsible for examined, decided, and resolved state administrative disputes. The authority of the State Administrative Court was carried out for state administrative disputes. The authority of the State Administrative Judicature was carried out for a state administrative dispute at the first level. While the state administrative dispute was at the appeal level, the authority to examine and decide to be in the hands of the state administrative high court. The division was filed the existence of a relative authority of the State Administrative Court.

The State Administrative Court was authorized to examined, decided upon, and resolved a state administrative dispute involving the public with state administrative officials. In this case, the authority of the State Administrative Court did not include the authority to handle state administrative disputes that occur within the armed forces. A state administrative dispute within the armed forces the jurisdiction of the military court to solve it.

Implementation of the authority of the State Administrative Court was conducted to resolve disputes between the litigants, so that justice seekers who feel harmed on a state administrative decision may protect by their rights. In this case, the authority of the State Administrative Court shall only arrive at the judgment of the case which has filed lawsuit. Based on Law Number. 51 of 2009 on the State Administrative Court, it was mentioned in Article 97 paragraph 7 that the Decision of the State Administrative Court may a lawsuit rejected, a lawsuit was granted, a lawsuit was not accepted, or a lawsuit fell. The verdict was a form of implementation of the authority of the State Administrative Court to resolve the state administrative dispute among the parties to the dispute. The authority possessed by a judicial body was tried a case can be distinguished into two, namely the authority of a relative nature and authority that is absolute. First, relative authority was the jurisdiction of the courts to try cases in accordance with their jurisdiction. Second, the absolute authority was the jurisdiction of a court judged a case by the object, matter, or subject matter of the dispute. The state 
administrative court as a court body also has two such powers. The relative authority of the State Administrative Court was described in Article 47 of the State Administration Judicature law, while the absolute authority of the State Administrative Court was based on the provisions of Article 1 point 10 of the law.Absolute, the Administration of State Administration Judicature was examined and judged two main points; there was state administrative dispute and civil service dispute. This is as regulated in Law Number. 5 of 1986 Article 1 point 10 that the state administrative dispute was a dispute arise in the field of state administration between a civil person or legal entity with a state administrative body or officer, both at the center and in the region, as a result of the issuance of the decisions of the state administration, including the civil service dispute based on the prevailing laws and regulations.

Regardless of the authority of the State Administrative Judiciary, not all powers to conduct the examination, termination of case or settlement of state administrative dispute was conducted by the State Administrative Court. There were special exceptions to a state administrative decision issued in certain situations that are not under the jurisdiction of the State Administrative Court. This matter was regulated in Article 49 of State Administration Judicature law. State administrative decisions issued in time of war, hazards, state of natural disasters, or extraordinarily dangerous circumstances shall not be the authority of the State Administrative Court to resolve disputes. In addition, state administrative decisions issued in urgent circumstances for public interest and taken under applicable laws and regulations were also outside the jurisdiction of the State Administrative Court to examine or to decide upon his/her dispute. The restriction was done because in the implementation of the state was not always an act of organizational state tools including administrative bestuur, but can also an action done by the state tool outside bestuur, but the tools of the state whose main duty to perform the functions of legislation and the judiciary was also authorized to issue a decision state Administration [11].

The object of a state administrative dispute was a state administrative decision issued by a state agency or administrative authority. The decisions referred to in this case ware decisions that negatively impact society or harm certain groups in society. However, in the case of a lawsuit against the Administrative Decree, there were several State Administrative Decisions which were an exception was sued in the State Administrative Court, as set forth in Article 2 of Law number 51 of 2009 concerning the second amendment to the law number 5 of 1986 follows:

a) Decision of state administration which was a civil law act;

b) Decision of state administration which was a general arrangement;

c) State administrative decisions that still required approval;

d) Decision of state administration was sued under the provisions of the criminal law code and the criminal procedure code of criminal law or other laws of criminal law;

e) Decision of state administration issued on the basis of the results of the examination of the judiciary in accordance with applicable laws and regulations;

f) Decision of the state administration concerning the administration of the national state of Indonesia;

g) The decision of the election commission was viewed or in the region regarding the results of the general election. 


\subsection{Steps that can be taken so that the Legal Protection of the Seeker can be binding}

The existence of state administrative courts in various modern countries, especially countries followed to welfare state was a milestone that became the foundation of the hope of society or citizens to defend their rights that were harmed by public legal acts of the agency or state administration officials because the decision issued.

Decisions gave at the last level by the court other than the Supreme Court may request by appeal to the Supreme Court. The cassation in this case was not meant to constitute the Supreme Court as a third-level court because the Supreme Court only conducts judgments on judicial jurisdiction and errors in procedural law, and in principle did not repeat the facts or incident (judex juris), in it was development, the Supreme Court as a cassation judiciary institution also casuistically domiciled as a judex juris institution as well as judex factie.

The examination of cassation was done by the Supreme Court as judex juris was due to the examination and verification of facts or incidents and the application of the law has done by the court of first instance and has reviewed at the appeal level. In its development, the cassation was used as a means to test a verdict of the first instance at the appellate level, not only limited to the application of the law but also to the written regulations of the unwritten law. Therefore, through the Supreme Court Supreme Court can arrange, guide and develop the law through jurisprudence, so that it can adapt the law to fit the development of society and especially the contextual interpretation of the laws and regulations when deemed inadequate or less able and out of touch with the motion of life dynamics socially, when there was a request for a cassation against a decision of the State Administrative Court accepted by the Supreme Court, then it means that the ruling may be annulled by the Supreme Court.

The Supreme Court recognizes that fair and transparent courts were established in order to bring about a quality judiciary. to achieve this, judges and judicial authorities must had adequate integrity, knowledge and skills.

To provide legal protection to justice seekers in order to be binding, the following steps may be taken:

1. Socialization to the public regarding the competence of the State Administrative Court and the supervision of the community against the decision;

2. Efforts that can be made to increase public understanding of the authority possessed by the State Administrative Court in this case were through broad socialization. Socialization can be done either from the State Administrative Court or from the Regional Personnel Agency

3. Require activeness from the litigant community to oversee the execution of the decision;

4. The activeness of the public who participate in the supervision of the implementation process of the judgment of the Administrative Court is necessary because the State Administrative Court only has authority to arrive at the decision of the case. as known, the Administrative Court does not have the executor of the judge's verdict because the executor on the State Administrative Court was the party subject to the verdict.

5. Inherent Control by Public Officials for Decisions Addressed to State Administration Officials;

6. For the State Administrative Officer subject to the decision by the Administrative Court of the State Administrative Court issued, the superior of the officer subject to the decision shall also provide supervision in order that the execution of the judgment can be made quickly and optimally. 
7. Implementation of Strict Sanctions In accordance with the provisions of the Laws and Regulations;

8. Implementation of sanctions for State Administration Officials who did not implement the decision has been regulated in Law Number 51 Year 2009 concerning State Administrative Court Article 116 paragraph (4) stating that "In the case of a defendant was unwilling to carry out a court decision which has had permanent legal force, concerned shall be liable to force of forced payment and / or administrative sanctions. Furthermore, Article 116 paragraph (5) of the State Administrative Justice Act states that "For officers who do not carry out court decisions, it shall be announced to the printed local media by the clerk from the non-fulfillment of such provisions".

9. Reporting from Administration Officials on the Implementation of Decisions Reported to the Administrative Court;

The reporting mechanism referred to in this case was the reporting of officials who are subject to verdict to the Administrative Court. The State Administration Officer subject to the decision shall be required to provide a report on the execution of the decision to the Administrative Court. Reports on the State Administrative Court in this case may serve as a means of control of an official subject to a ruling by the Administrative Court.

\section{CONCLUSIONS}

Based on the things that had been mentioned above, then the conclusions of research that can be taken is as follows:

1. Legal protection granted by the State Administrative Court can be realized if there was a good will from the Board or the State Administration Officer itself, because the process of execution of the verdict was directly in the hands of the party subject to the decision in this case the Board or the State Administration Officer.

2. The steps taken to make legal protection for justice seekers more binding, namely:

a. Socialization to the public about the competence of the Administrative Court and the supervision of the community against the decision;

b. Require activeness from the litigation community to oversee the execution of the decision;

c. Supervision was attached by a public official to a decision directed to the State Administrative Officer;

d. Adoption of strict sanctions in accordance with the provisions of legislation; Reporting from administrative officials on the execution of decisions reported to the State Administration Court.

\section{REFERENCES}

[1] Y. J. Utama, "Legal Protection Efforts for Society Conducted by State Administrative Court," Semarang, 1995.

[2] P. Atmosudirjo, Issues of Development of Administrative Court in Indonesia. Bandung: Eresco Cinemara Hukum, 1979.

[3] M. B. Miles and A. M. Huberman, Analisis Data Kualitatif. 1992.

[4] P. M. Marzuki, Penelitian Hukum. Jakarta: Kencana Prenada Media Group, 2009. 
[5] D. S. Lev, Lembaga Peradilan dan Budaya Hukum di Indonesia. Jakarta: Pustaka Sinar Harapan, 1988.

[6] P. Nonet and P. Selznick, Hukum Responsif: Pilihan di Masa Transisi [Law and Society in Transition: Toward Responsive Law]. Jakarta: HuMA, 2003.

[7] S. Rahardjo, Sisi-Sisi Lain dari Hukum di Indonesia. Jakarta: Penerbit Buku Kompas, 2004.

[8] Y. J. Utama, "Menggugat Fungsi Peradilan Tata Usaha Negara Sebagai Salah Satu Akses Warga Negara Untuk Mendapatkan Keadilan dalam Perkara Administrasi Negara," 2007.

[9] S. Basah, Perlindungan Hukum Terhadap Sikap Tindak Administrasi Negara. Bandung: Alumni, 1997.

[10] Indroharto, Usaha Memahami Undang-Undang Tentang Peradilan Administrasi Pemerintahan, Buku I, Beberapa Pengertian Dasar Hukum Tata Usaha Negara. Jakarta: Pustaka Sinar Harapan, 1996.

[11] D. H. Koesoemahatmadja, Pengantar hukum tata usaha negara Indonesia. Bandung: Alumni, 1975. 